\title{
Developing Plurilingual Children: Parents' Beliefs and Attitudes towards English Language Learning and Multilingual Learning
}

\author{
Eleni Griva ${ }^{1, *} \&$ Panagiota Chouvarda ${ }^{1}$
}

${ }^{1}$ Faculty of Education, University of West Macedonia, 5310 Florina, Greece

*Corresponding author: Eleni Griva, Faculty of Education, University of West Macedonia, 5310 Florina, Greece. E-mail: egriva@uowm.gr

Received: August 26, 2012

Accepted: September 21, $2012 \quad$ Published: September 25, 2012

doi:10.5430/wjel.v2n3p1

URL: http://dx.doi.org/10.5430/wjel.v2n3p1

\begin{abstract}
The present study was conducted with the aim to provide an account of parents' beliefs on issues related to their children's EFL and multilingual learning in the Greek educational context. The stimulus for conducting the study can be identified in the spread of English world-wide and the changing status of English within Europe along with the crucial role of parental attitudes to their children's foreign language learning. In total, the views of 50 parents of primary school children were surveyed. Semi-structured interviews were used as the basic research instrument. It should be noted that although the parents acknowledged the influential role and dominance of English as a lingua franca, they highlighted the need for students to acquire multilingual competence in a variety of foreign languages.
\end{abstract}

Keywords: Early EFL learning, Plurilingual education, Parents, Beliefs

\section{Introduction}

In a multilingual and multicultural Europe, the mastery of languages contributes to promoting mutual understanding and communication among people of different nationalities, as well as to developing multilingual awareness and multicultural sensitivity (Lüdi, 2006). In other words multilingualism could be served as a valuable advantage in a globalized society. The European Commission emphasized that "language learning is one of the most basic skills that each citizen should have in order to actively participate in the understanding of the European community and it facilitates social cohesion" (Commision of the European Communities, 2008). The European Commission agreed upon an action plan for the European cooperation towards education and training (ET, 2020), which was adopted in May 2009 and aims to make life-long learning and student's mobility a real thing, develop education's quality and efficiency of training, promote equality, social cohesion and citizen's involvement in social issues, and finally enhance creativity and innovation in all educational levels (European Commission, 2011). Nevertheless, in those contexts English language plays a major role in every aspect of the contemporary world, since it is considered to be the "lingua franca" (Crystal 2003).The function of English as a global language has led to its introduction as a core subject in most European education systems. In some cases the first foreign language -which is usually English- is obligatory and children have the opportunity to start learning a second foreign language from primary education (Griva\&Iliadou, 2010). Almost $30 \%$ of the European member states have introduced early language learning, although this differs across different contexts (EuropeanCommission, 2008).

In Greece, English as a foreign language has been a compulsory subject in the primary school curriculum from the $3^{\text {rd }}$ grade onward for the last years (Official Gazette: Law 1325/16-9-2001) while it has been introduced on a pilot basis from $1^{\text {st }}$ grade onwards in a number of schools in the year 2011-2012 (Griva, Chostelidou\&Panteli, 2012). In 1992-93, English was established as the first compulsory foreign language in lower secondary education while a second compulsory foreign language, either French or German, was introduced in lower secondary education (L.Decree 447/1993 in Griva, 2004). In the school year 2005-2006, the introduction of a second foreign language (French or German) was piloted as compulsory subject at a number of primary schools from $5^{\text {th }}$ grade onwards (Circular $\mathrm{F}$ $52 / 345 / 48265 / \mathrm{C} 1 / 17-5-2005)$. Furthermore, in 2008 Italian was piloted as a second foreign language in lower secondary education (Circular I 11800/C2/2-9-2008) (Griva\&Iliadou, 2010). 
Researchers such as Johnstone (2009) and Graddol (2010) clarified that early language learning, is an innovative language policy with lifelong results (Enever et al., 2009). There is a variety of research findings showing the beneficial impact that early foreign language learning has on children's cognitive and linguistic skills (Blondin et al., 1998). This means that during early language learning programs, students acquire high level of linguistic skills compared to students who start studying foreign languages later in their lives. Mastering compentence in a foreign language results into political, social, cultural and intellectual benefits (Blondin et al., 1998).

Moreover, children's early exposure to a second language a) contributes to enhancing their creativity and flexibility, thus their intellectual development (Hamayan, 1986), b) provides them the opportunity to broaden their mind and their perception, to obtain holistic understanding, to expand their understanding of language as a phenomenon and c) gives them the ability to reach a high level of linguistic competence, a basic factor for their educational choices and professional rehabilitation. In addition, other studies revealed that early language learning brings beneficial results on children's memory strategies and listening skills (Hamayan, 1986).

\section{The study}

\subsection{Rational and purpose of the study}

Parents', teachers' and students' beliefs are extremely important, since they can contribute to conversations concerning the status of foreign languages and have an impact on every language policy decision and determine a new direction for multilingual education, (see Griva\&Chostelidou, 2011;Nespor, 1987). Family can play a crucial role in terms of strengthening children's positive thinking towards foreign languages. Parental attitudes towards foreign languages affect their children's success in multilingual competence. Both the way in which parents feel about foreign languages and the way they behave affect the linguistic development of their children (see Young, 1994).

A number of research findings related to parental attitudes towards early language learning indicated the positive effect of their stances on children's language education. Especially in 2006, in Taiwan, a research conducted by the Government Information Office revealed that most parents were positive towards early language learning and they supported English learning even from the nursery school. Another research which was conducted in Korea showed that in South Korea parents used to send their primary school children in countries where English is the official language in order to learn English in a natural context. In Korea, many parents believe that early language learning contributes to psychosocial, linguistic and educational progress of the children (Newell, Graves \& Jose, 2011).

The power of networking among parents' beliefs and attitudes and their active involvement in the support of their children's schooling has been indicated by Sheldon (2002). Also it has been revealed that a) parents' attitudes may be influenced by their own knowledge or lack of another language and their experience with a L2/FL (Bartram, 2006); b) parents' involvement may be differentiated by gender based on the traditional roles of ' male' and 'female' (Watzke, 2003).

The scarcity of research concerning Greek parents' beliefs about children's foreign language education was a further stimulus for conducting the present study, which aimed at providing an account of parents' beliefs regarding issues related to their children's foreign language (FL) learning and an early EFL (English a a foreign language) learning. The study is a part of a larger research project conducted in Greece, which also surveyed students' attitudes as well as FL teachers' and views and beliefs about the implementation of a multilingual policy and the influential role of English as a lingua franca in the Greek context (see Griva \& Chostelidou, 2011; Griva, Chostelidou \& Panteli, 2012). More precisely, the present study aimed at:

i) specifying parents' perceptions of central issues on their children's foreign language learning;

ii) identifying their attitudes to English as a lingua franca

iii) recording their views on early EFL learning;

iv) recording their involvement in their children's foreign language education;

v) identifying any factors, such as gender and age, that affect parents' beliefs.

\subsection{Sample}

The participants for this study were 50 randomly selected parents ( 30 women and 20 men)of children attending the first or second year of primary school. 24 parents declared they can speak one foreign language, 23 parents can speak two foreign languages, only 3 parents declared they cannot speak a foreign language. 


\subsection{Instrument}

Semi-structured interviews were used as the basic instrument to collect that data, which comprised the following sections: a) conceptualization of multilingualism, b) the role of ELF, c) introduction of EFL in early stages of education, d) suggestions about multilingual education.

The interviews were conducted individually, and were tape recorded, transcribed and analysed both qualitatively and quantitatively. The verbal data underwent both qualitative and quantitative analysis. a) Concerning the qualitative analysis, the following procedures were followed: Data reduction, which involved first and second level coding, resulted in groups of categories/sub-categories; then similar categories with common characteristics were clustered into basic themes (Miles \&Huberman, 1994). b) In relation to qualitative analysis, frequencies and percentages for all categories/subcategories were obtained. The non parametric test Mann-Whitney was used in order to identify differences in parents' attitudes and perceptions in relation to gender and age.

\section{Results}

Coding of the verbal data resulted in 73 codes, which were grouped into 18 categories of five basic themes (see tables 1, 2, 3, 4, 5):

A. Aspects of multilingualism in Greece.

B. The status of English language.

C. Early EFL learning.

D. Parental involvement in children's foreign language learning.

E. Suggestions about foreign language learning in Greek education.

\subsection{Aspects of multilingualism in Greece}

Multilingualism is a global phenomenon existing even in Greece, which is a E.U member state. The usefulness of learning foreign languages for communication reasons is unquestionable. The majority of the parents declared that it is of vital importance to speak at least two languages in order to communicate: ".......in order to communicate with people from other nationalities and it is a vital tool to find a job"(parent 46). It was also believed that learning many foreign languages is necessary for educational and vocational reasons: "I believe that it is a necessary tool in order to speak and give information to a tourist, to use the internet and to find a job in the future"(parent 30). A lot of parents showed a positive attitude towards foreign language learning because they agreed upon the demanding needs in the contemporary world. Many parents expressed the desire for equal treatment among European countries so speaking many foreign languages contributes to that. Moreover, multilingualism gives the chance to participate in European exchange programs. A mother stated that: "A student may later take part in exchange programs (...)” (parent 49). On the contrast, there are some parents who are negative towards learning foreign languages due to their belief of indirect "imposition" from other countries: "I think that, we consider sometimes the examples of other countries and we try to imitate them" (parent 50). Moreover, some parents, talked about foreign languages in Greek education and most of them agreed upon the inefficient way in which they are taught: "If that was taught efficiently (...)" (parent 38). Lastly, some parents talked about the advantages of introducing a $2^{\text {nd }}$ foreign language and a parent stated characteristically: "Another advantage maybe that children may become familiar with other civilizations and customs and that would help them to get away with racist behaviors" (parent 49). 
Table 1: Categories and codes of the thematic strand: Aspects of multilingualism in Greece

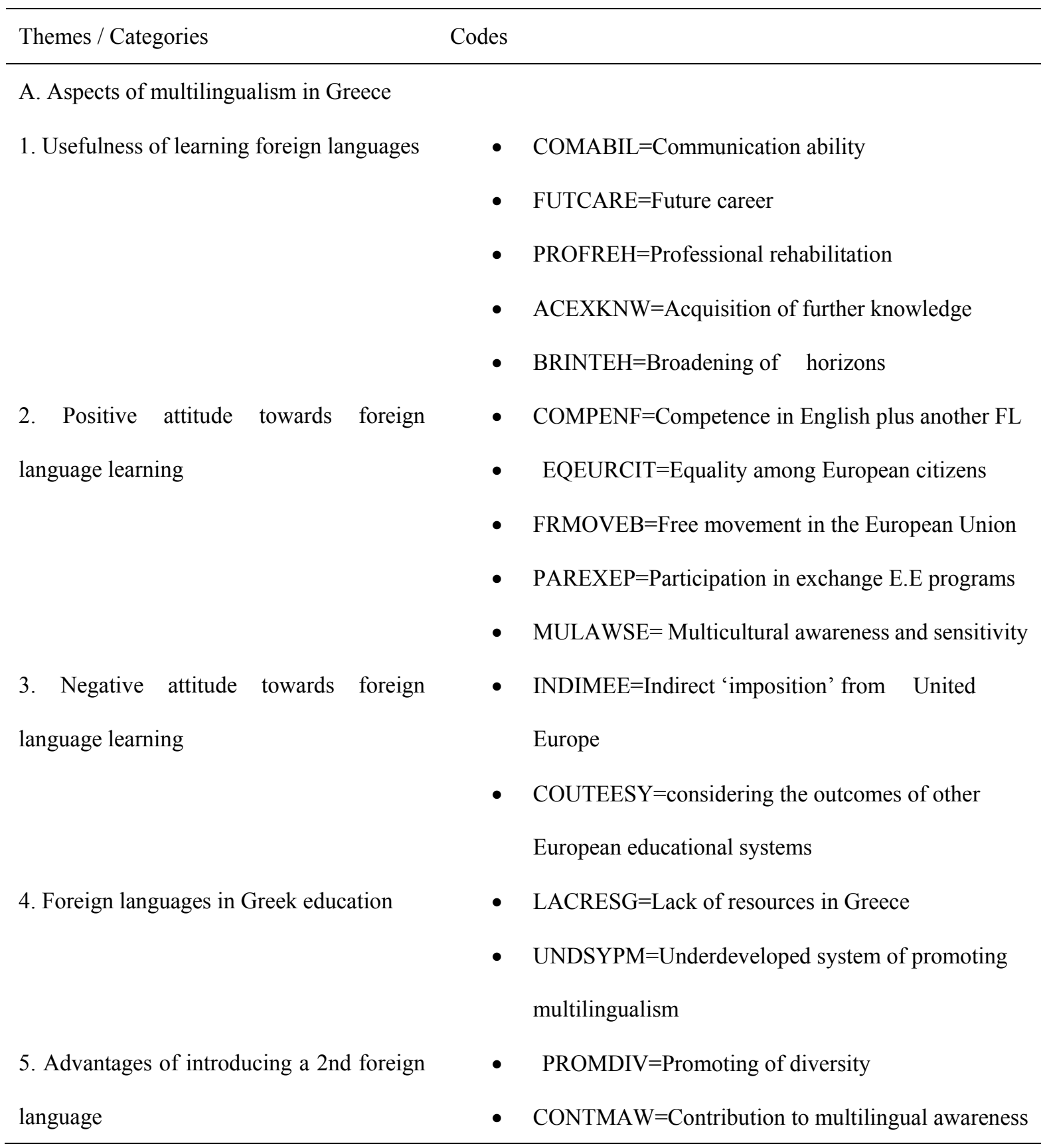

Concerning the category 'usefulness of learning foreign languages', the non parametric test Mann-Whitney indicated statistically significant differences in parental opinions in relation to their gender $(z=-2,415, p=0,016)$; the male parents $(\mathrm{m}=0.88, \mathrm{std}=.354)$ seemed to believe more strongly that learning a foreign language is a vital tool for their children's future than the female parents $(\mathrm{m}=0.40$, std=.497). It is also worth mentioning that the men strongly considered (mean rank=35.38) multilingual ability as a basic factor for children's Professional rehabilitation in the future compared to women (mean rank= 23.62). In addition, men (mean rank=32.38) mostly agreed on the fact that multilingual ability could contribute to broadening of children's horizons compared to women (mean rank=24.19). Moreover, the non parametric test Kruscall-Wallis indicated statistically significant differences among parents of different ages $\left(1^{\text {st }}\right.$ group $25-35$ years old, $2^{\text {nd }}$ group $35-45$ years old, $3^{\text {rd }}$ group over 45 years old) in relation to the 'usefulness of learning foreign languages' ( $\mathrm{t}=7,230, \mathrm{df}=2, \mathrm{p}=0,027$. More precisely, the younger parents (25-35 years) $(\mathrm{m}=1.00$, std $=.004)$ insisted more on the usefulness of multilingual ability for communication purposes than the 
parents of over 35 years old $(\mathrm{m}=0.39$, std $=.494)$. However, older parents (over 45 years old) indicated the necessity of learning foreign languages for their children's professional rehabilitation in the future $(\mathrm{m}=33.50)$ compared to the younger ones $(\mathrm{m}=19.75)$. Additionally, significant differentiations were revealed between parent's age and their opinions about the broadening of children's intellectual horizons, since the younger parents $(\mathrm{m}=0.75$, std $=.516)$ insisted more on the fact that learning a foreign language could result in broadening horizons than the older parents, aged 35-45 $(\mathrm{m}=0.17, \mathrm{std}=0.378)$. In addition, the non parametric test Kruscall-Wallis revealed significant differences between the age of parent and their views in relation to opportunities that can be provided by participating in European exchange programs $(\mathrm{t}=11.500, \mathrm{df}=2, \mathrm{p}=0.003)$. More precisely, it was the younger parents $(\mathrm{m}=0.25, \mathrm{std}=.500)$ who stronger believed that the competence in a foreign language can help children participate in such programs than the older parents $(\mathrm{m}=0.3, \mathrm{std}=.005)$.

\subsection{The status of English language}

Through the qualitative analysis it was revealed that the majority of the parents agreed on a) the importance of the English language in everyday life and its role as lingua franca - a common communication code; $b$ ) the necessity to learn English as a foreign language since it is considered to be a very useful tool for the academic and vocational future of their children. Most of the parents agreed that English is needed mainly in communication and mutual understanding with other European Citizens: "I think that it is the language that a child can use in order to communicate with others" (parent 33). Furthermore, English is used as a lingua franca in many everyday aspects such as trade, technology, song lyrics and mass media. A mother typically stated: "A common language should exist within Europe in order to communicate more easily (...)” (parent 43). The English hegemony over other languages is also true. The worldwide power of English has resulted in gradual extinction of other European languages and worse than that to English loans in Greek language: "We see that children don't use Greek correctly because of greeklish in PC (...)" (parent 2). Furthermore a father mentioned that: "English has reined in many different ways over other languages such as Spanish and Italic (...)” (parent 30).

Table 2: Categories and codes of the thematic strand: The status of English language

B. The status of English language

6. Usefulness of English language

7. English as lingua franca

8. Hegemony of English over other languages
- EALELAN=Easy learning of other languages

- COMUNEC $=$ Communication and mutual understanding of other European Citizens

- MEGLCOM=Means of global communication

- $\quad$ TECHLIT $=$ Technological literacy

- GREXEUL $=$ Gradual extinction of other European languages

- WPOWENL=Worldwide status of English language

- $\quad$ PRENEVL=Presence of English in all aspects of everyday life

- PROELDO=Protection of other European languages from the dominance of English 
The non parametric test Kruscall-Wallis revealed statistically significant differences, in the usefulness of English as a lingua franca for communicative purposes, in relation to parent's age $(t=9.126, d f=2, p=0.010)$. The younger parents (25-35 year old) stressed the importance of learning English for communication and mutual understanding to a higher degree $(\mathrm{m}=1.00, \mathrm{std}=.002)$ than the parents of $35-45$ years old $(\mathrm{m}=.39, \mathrm{std}=.494)$ and the parents of over 45 years old $(\mathrm{m}=.80, \mathrm{std}=.422)$. Moreover, the younger parents insisted on the usefulness of English in the development of technological literacy. $(\mathrm{M}=0,25$, std $=0,50)$ compared to the older ones $(\mathrm{M}=0,00, \mathrm{std}=0,00)$.

\subsection{Early EFL learning}

Among the factors which affect parent's attitude towards early language learning, it was found that they may be emotional reasons i.e the need to acquire new knowledge or exterior factors such as globalization. A parent stated that: "Personally, I didn't learn foreign languages but that didn't benefit me" (parent 8) or as it was suggested by another mother: "The social needs of contemporary world contribute to the promotion of early foreign language learning" (parent 18).

Some parents were positive towards Ministry's decision to introduce English from the first years of primary school. They agreed with the statement "as early as possible". Nevertheless, early foreign language learning was stated to be effective if it takes place in a game-based environment: "Teachers should not teach grammar but tales, songs and paintings" (parent 13). Some other parents insisted on the appropriate methodology in teaching young children: "I agree but I insist on the correct methodology and Curriculum" (parent 23). There were some parents, who stated that at the age of 6-7, children are mature enough to communicate: "A 6 year old child is mature enough to communicate in a second language" (parent 35).

On the contrary, there were some parents who showed a negative attitude towards early language learning, as they reportedly believed that children of five - six years old are immature for learning L2. It was supported that children need to primarily consolidate their mother tongue at a considerable level prior to getting involved in the process of acquiring another language: "I believe that it is too early to learn a foreign language and it is difficult for a child to respond" (parent 36), "children are unable (...)" (parent 26). Parents were constantly suggested the prerequisites for early EFL introduction; for example, teaching in a playful way, using new technologies which is attractive to young children and using a variety of games: "It must be introduced in a playful way and through a computerized learning" (parent 40), "I totally agree if it is as a game" (parent 6), "Children should have free time to play" (parent 18). Additionally, bilingual students should also be taken under serious consideration because they usually have difficulty in using a foreign language other than their native. These students may feel anxious and pressed to understand a foreign language when they use another language at home. Most of the parents talked about the equality that these students should have in their education with Greek students. Concretely, a mother said: "For me, nationality plays a minor role in foreign language learning. From the moment that this student goes to a Greek school and follows the same curriculum with Greek students, we cannot marginalize them. We should always give them equal chances" (parent 47). Concerning the link between foreign language learning and other subject areas (content based language learning), many parents believe that there is no strong relationship between the two and they are unrelated learning domains. They stated that students use different cognitive strategies for mathematics and others for English. A mother said: «I think that we cannot compare the two, they require different brain processes. Mathematics is a different subject and requires another logic» (parent 47).

Concerning their attitudes towards early EFL learning, it was revealed that men (mean rank=26.31) placed more emphasis on the methodology used for young children than women (mean rank=21.25). On the other hand, women (mean rank=26.45) insisted on considering the positive outcomes of the plurilingual education systems of other countriesthan men (mean rank=20.50).

Moreover, the younger parents were found to place more emphasis on the methodology used for young children than women (mean rank=27.50) than the older ones (mean rank=27.50). On the other hand, the older parents (mean rank=27.45) insisted on considering the positive outcomes of the plurilingual education systems of other countriesthan the younger ones (mean rank=20.50). 
Table 3: Categories and codes of the thematic strand: Parents' attitudes towards early EFL learning

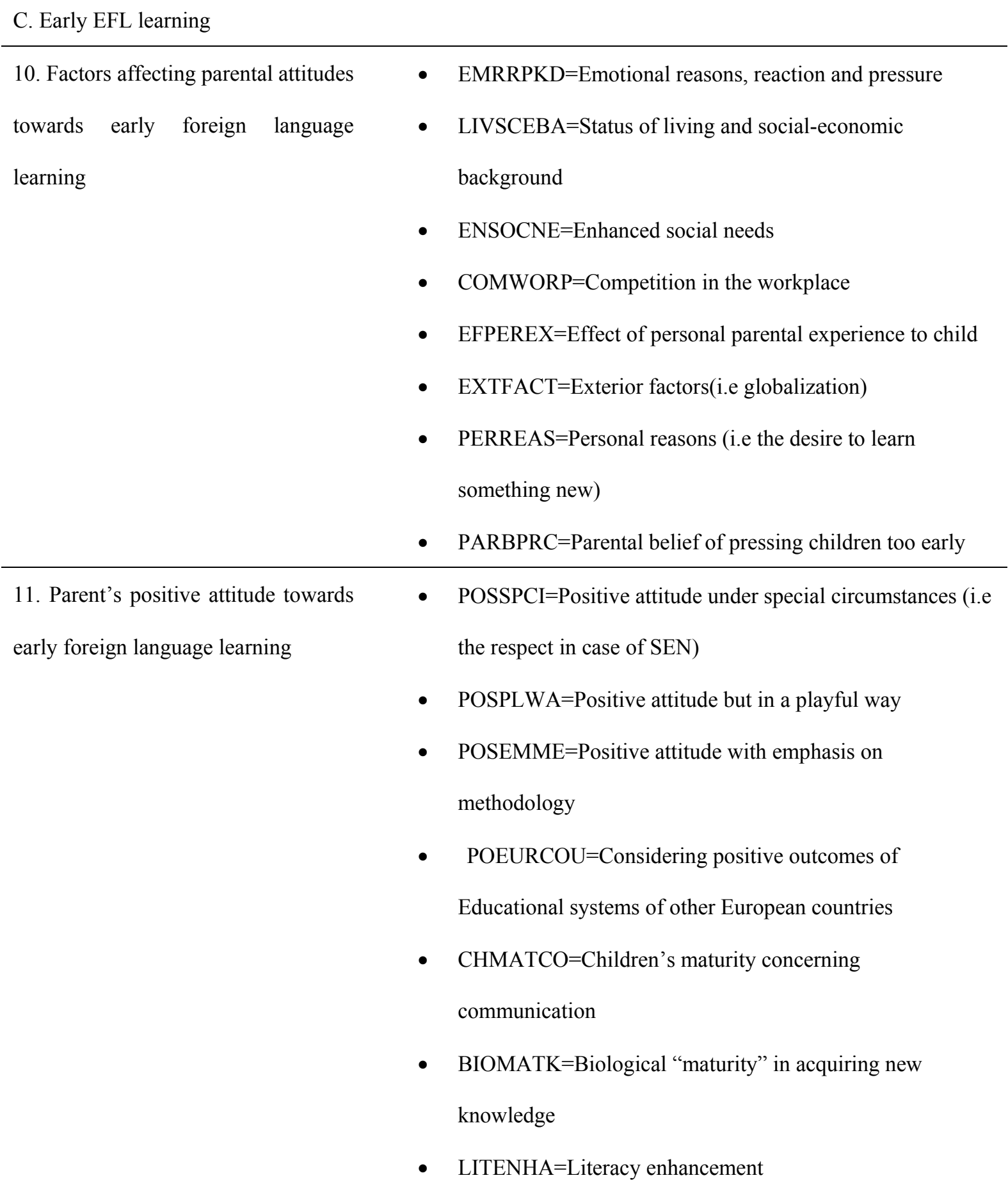

\footnotetext{
12. Parent's negative attitude towards

- $\quad \mathrm{KNOWBUR}=$ knowledge burden

early foreign language learning

- CONACL1=Confusion in acquiring L1

- CHCOGIM= children's cognitive immaturity
} 


\begin{tabular}{ll}
\hline 13. Prerequisites for early EFL & - USNETEC = Use of new technologies \\
introduction & - PLSUPEN $=$ Playful and supportive classroom environment \\
& - EXFRTPL = Existence of free time to play \\
\hline
\end{tabular}

14. Early foreign language learning

- $\quad$ PRLOPST=Provision of learning opportunities to

and bilingual children

students

- $\quad$ EQRITST=Equal rights to bilingual students

- $\quad$ RACBEAG=Racist behavior against them

- $\quad$ PSYPRGR=Psychological pressure from the Greek students

- $\quad$ DIFENBIL $=$ Difficulties encountered by bilingual children

15. Linking of foreign language

learning with other subject areas
- DIFCOSTR=Different cognitive strategies used in other subjects

- EQTIMLF=Equal time allotted in both learning fields

- INDLEFL=Independent learning fields

- UNRELDO=Unrelated domains

\subsection{Parental involvement in children's foreign language learning}

The majority of the parents told that they help their children in the foreign language learning by answering some questions, by helping them to understand new vocabulary and grammar and by encouraging them to learn new things (table 4). Parent's behavior and involvement is closely related to their education and professional background. An important parental attitude was that of showing respect towards the personality and talents of a child. A mother marked: "I think that each child has its own personality and willingness and we should respect that" (parent 5). A lot of parents emphasized the fact that due to external children's stimulus, the role of parents is marginalized and therefore children react according to external motives: "I believe that they are motivated to learn new things and reveal it by themselves" (parent 8).

Most of the parents declared they help their children in foreign languages because of personal satisfaction to get involved in the process of English language learning as well as their high educational level and their competence in the target language: "Personally, I help her because I like English a lot and I have Lower" (parent 7). They also believed that a child is more positive towards learning a foreign language when the parents encourage him/her to learn the target language. 
Table 4: Categories and codes of the thematic strand: Parental involvement in children's foreign language learning

D. Parental involvement in children's

foreign language learning

16. Complexity of parental role
- $\quad$ CONSTSL=Contribution to students learning

- $\mathrm{MARGPCH=Marginalization} \mathrm{of} \mathrm{parental} \mathrm{role}$ due to external children's stimulus

- $\quad$ RESCPTA=Respect to child's personality

- $\quad$ PARCFOL=Parent's influence on children's FL choosing due to personal motives

- $\quad$ SUPPARL=Supportive parental role

- $\quad$ CONPARL $=$ Counseling parental role

- $\quad$ PARDEIL=Parent's desire due to their lack of knowledge

\subsection{Suggestions about foreign language learning in Greek education}

Through parents' interviews, it was revealed parents' dissatisfaction with the way in which foreign languages are taught in Greek public schools, due to inappropriate teaching methods and techniques and inadequately trained teachers to teach to the young learners (table 5). A mother stated that: "The teaching staff isn't suitably trained to teach young children and the time allotted in English isn't adequate (...)" (parent 31). Another mother reported: "Parents consider English as a void hour, as game not as a school subject" (parent 5).

Many parents suggested that a more communicative approach should be adopted for FL Teaching/Learning in order to motivate young learners: "We should make them learn English but not as school subject but as game, which will make them happy and under no responsibilities" (parent 47). For this reason, the Greek educational system should adopt an efficient curriculum and appropriate materials as well as attractive textbooks: "The only thing we do as a Greek educational system, is to add new technologies, textbooks and foreign languages without the suitable organization and as result children acquire only information and no valuable knowledge" (parent 37). In addition, most of the parents expressed their wish that Greek public school would provide students with English language certificates: "I wish that children would obtain an English certificate through public school" (parent 34). 
Table 5: Categories and codes of the thematic strand: Suggestions about foreign language learning/teaching in the Greek education

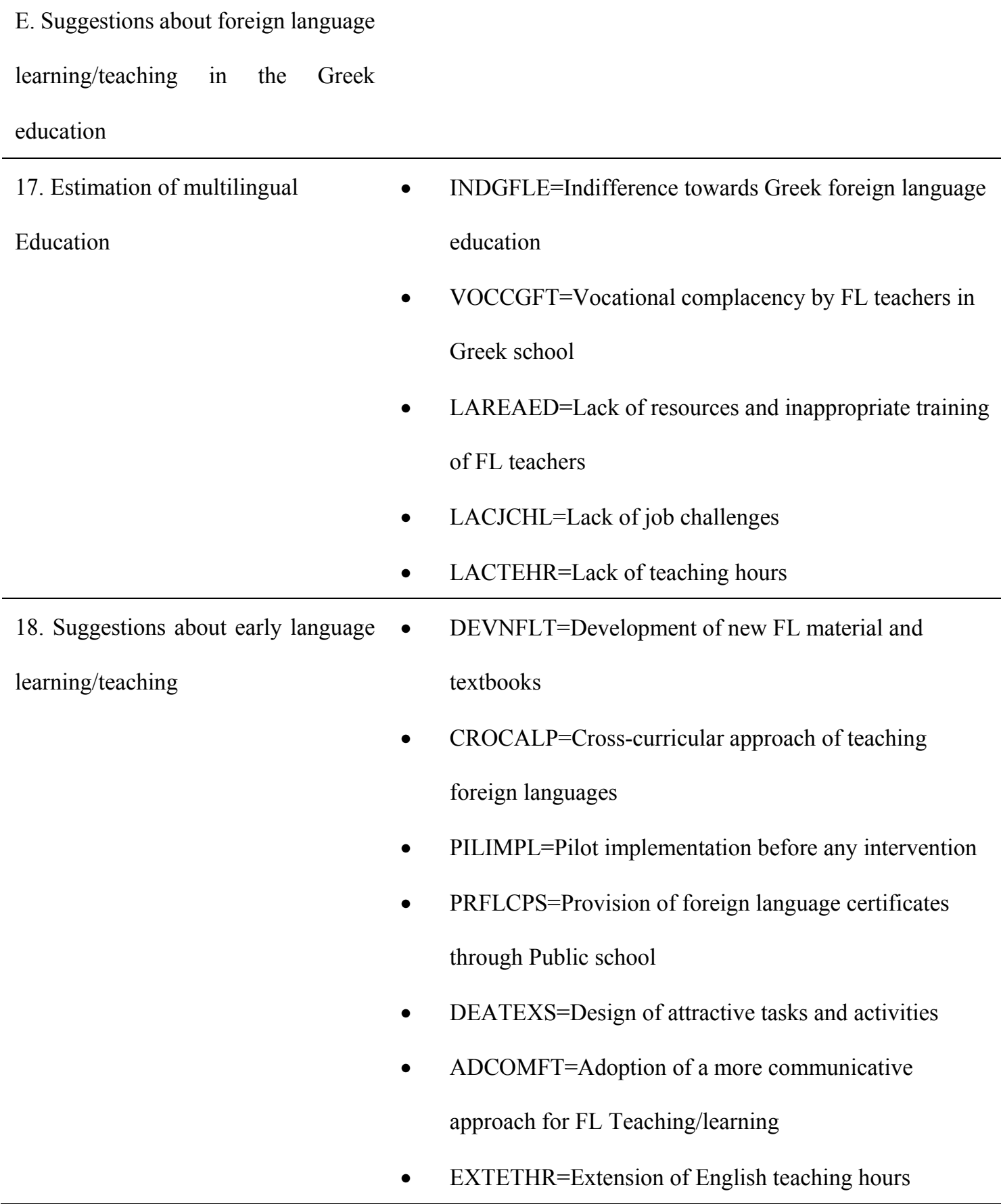

\section{Discussion}

The main objective of the study was to identify parents' opinions and attitudes towards their children's foreign language education and early EFL learning. The parentsacknowledged the usefulness of English language in the contemporary globalized world and underlined the necessity for every citizen to learn English which has established itself as a 'global language' (Crystal 2003). They also supported the need for their children to acquire multilingual competence in a variety of foreign languages, since it helps children to communicate, to find a job more easily, to travel abroad and to broaden their horizons. Male parents, aged between 25 and 35 years old, believed that multilingual 
learning facilitates communication and is an asset for the future as it contributes to vocational rehabilitation (Shipton et al., 2006). Moreover, younger parents (25-35 years old) strongly regarded learning foreign languages as a useful tool to broaden children's horizons as well as to develop positive attitudes to other languages and cultural awareness (Kennedy et al., 2000).

In addition, the benefits of learning EFL from a very young age (European Council, 2002) were highlighted by the majority of the parents, as it was agreed that young children can learn FLs easily and quickly (see also Griva\&Chostelidou, 2011). Only a small number of the participants showed a negative attitude towards early foreign language learning, because they believe that children are cognitively "immature" to acquire a second language at this age. It is worth mentioning that the parents were positive towards the early language learning under certain terms. More precisely, they suggested that English should be taught in a playful way during the first primary school grade. Also, the educational and teaching techniques should be suitable for their age and curricula and timetable should be appropriately adapted (Nunan, 2003; Hayes, 2007). The teaching material and activities should promote communicative skills and be attractive for young learners. Moreover, FL teachers should be appropriately trained to respond to early language learners' needs and to any special educational needs when they arise. In other words, English language teachers for young ages should receive efficient and appropriate training and specialization in order to accomplish their role (Alexander, 2002).

The consequences of using inappropriate teaching methods may provoke negative effects on students' performance, self-confidence self-respect and attitudes towards the target language. Early foreign language learning is an "educational treasure " (Blondin et al., 1998). However, if any early language program is implemented without having been carefully and adequately designed and piloted, the outcomes may be ineffective. For instance in 1990, when the Government of Bangladesh decided to introduce English in the first years of primary school under no planning and without using any innovative teaching methods, children did not show a satisfactory competence (Hoque, 2009).

It was highly supported that school environment plays a significant role in the creation of positive feelings about foreign languages (ELLiE, 2008). It was also pointed out the importance of cooperation and communication among achieve a successful learning outcome. Strong ties between parental involvement and children's academic and behavioral success may contribute to children's high performance (Berthelsen\& Walker, 2008). The majority of the parents declared that they encourage their children to learn foreign languages by answering questions and helping their children to learn English. A possible obstacle in parental involvement is foreign language deficiency due to the low educational level and background.

Concluding, it is stated that parental attitudes play a vital role in motivating children to learn EFL as early as possible and to acquire communicative skills in various foreign languages. The parents who participated in the present study strongly believed that multilingual awareness and ability as well as early language learning has a beneficial effect on both children's personality and their vocational rehabilitation in the future.

Despite the research findings and implications described above, the present study is not without limitations which mainly concern the relatively small sample size. The generalisation of the parents' beliefs recorded in the present study to other populations with different educational and social backgrounds may be limited. In this respect, further research is needed that may provide us with further information that can be generalized.

\section{References}

Alexander, N. (2002). Bilingual education as a transitional strategy in post-colonial Africa. In: T Becket (Ed.), Reports on mother-tongue education, (pp. 3-10). Cape Town: PRAESA.

Bartram, B. (2006). An examination of perceptions of parental influence on attitudes to language learning. Educational Research, 48(2), 211-221. http://dx.doi.org/10.1080/00131880600732298

Berthelsen, D., \& Walker, S. (2008). Parents' involvement in their children's education. Australian Institute of Family Studies. Family Matters, 79, 34-41.

Blondin, C., Candelier, M., Edelenbos, P., Johnstone, R., Kubanek-German, A., \& Taeschner, T. (1998).Foreign Languages in Primary and Pre-school Education. A Review of Recent Research within the European Union. London: Center for Information on Language Teaching and Research.

Brown, J. D. (2001). Using surveys in language programs. Cambridge: CambridgeUniversity Press. 
Commision of the European Communities (2008).Communication from the commission to the European Parliament, the council, the European economic and social committee and the committee of the regions. Multilingualism: an asset for Europe and a shared commitment.COM(2008) 566 final. Brussels

Crystal, D. (2003). English as a global language. Cambridge: Cambridge University Press. http://dx.doi.org/10.1017/CBO9780511486999

EARLI (2009). Early Foreign Language Learning in Europe. Challenges of Data Collection in a Multinational Study. ELLiE Research team. Amsterdam.

Enever, J., Moon, J., \& Raman, U. (2009).Young Learner English Language Policy and Implementation: International Perspectives. Reading, UK: Garnet Education/ IATEFL.

English in Action. (2009). Baseline Study 1.An Assessment of spoken English competence among students, teachers and adults in Bangladesh. Research Report, English in Action. Dhaka, Bangladesh.

European Commission. (2008). European Strategic Framework for Education and Training Language Learning at Pre-Primary School Level: Making it Efficient and Sustainable. A Policy Handbook.Brussels.

European Commission. (2011). 'Education and Training for a smart, sustainable and inclusive Europe' Analysis of the implementation of the strategic framework for European cooperation in education and training (ET2020) Country analysis. Commission Staff Working Document SEC(2011) 1607. Brussels.

European Council. (2002). Barcelona European Council.Presidency Conclusions. Retrieved from http://www.cilt.org.uk/home/policy/policy_articles_listing/conclusions,_europe an_council.aspx

Gardner, R. C. (1985). Social Psychology and Second Language Learning. London: Edward Arnold.

Government Information Office. (2005). Taiwan Year Book 2005. Taipei, Taiwan Author.

Graddol, D. (2010). English Next in India. British Council.

Griva, E., \& Chostelidou, D. (2011). Multilingual competence development in the Greek educational system: FL teachers' beliefs and attitudes. International journal of multilingualism, 1-15.Multilingual matters.

Griva, E., \& Iliadou, S. (2011). Foreign Language policy addressed to Greek primary and secondary education: teachers' viewpoints and students' attitudes towards plurilingualism. European Journal of Language Policy, 3(1), 15-35. http://dx.doi.org/10.3828/ejlp.2011.3

Griva, E., Chostelidou, D., \& Panteli, P. (2012). ELF and multilingualism in Greek and Cypriot educational system: a comparative account of teachers' beliefs. Paper presented at the fifth International Conference of English as a Lingua Franca, Bogazici University, Istanbul - Turkey.

Hamayan, E. (1986). The Need for Foreign Language Competence in the United States. ERIC Digest. Retrieved from: http://www.ericdigests.org/pre-924/need.htm

Hayes, D. (2007). English language teaching and systemic change at the primary level: Issues in innovation. In Powell-Davies, P. (Ed), Primary Innovations. Selected papers from the Regional Seminar. Hanoi: British Council.

Hoque, S. (2009).Teaching English in English Primary Schools in Bangladesh: Competencies and Achievements. In Enever, J., Moon, J. \& Raman, U. (Eds), Young Learner English Language Policy and Implementation: International Perspectives. Reading, UK: Garnet Education/ IATEFL.

Johnstone, R. (2009). An early start: What are the key conditions for generalized success? In J. Enever, J. Moon \& U. Raman (Eds.), Young Learner English Language Policy and Implementation: International Perspectives, (pp. 31-41). Reading: Garnet Education.

Kennedy, T. J., Nelson, J., Odell, M. R. L., \& Austin, L. K. (2000).The FLES attitudinal inventory.Foreign Language Annals, 33(3), 278-289. http://dx.doi.org/10.1111/j.1944-9720.2000.tb00606.x

Lüdi, G. (2006). Multilingual Repertoires and the consequences for linguistic theory. In K. Bührig\& J. D. Thije (Eds.), Beyond misunderstanding: Linguistic analyses of Intercultural communication, (pp.11-42). Amsterdam: John Benjamins B.V.

Miles, M. B., \& Huberman, A. M. (1994). Qualitative data analysis (2nd ed.). Thousand Oaks, CA: Sage.

Nunan, D. (2003). The Impact of English as a Global Language on Educational Policies and Practices in the Asia-pacific Region. TESOL Quarterly, 37(4), 589-613. http://dx.doi.org/10.2307/3588214 
Papadopoulou, V. (1999). Observation of teaching: Theoretical context and implementation. Thessaloniki: Kiriakidi. Rosenbush, M. H. (1987). Foreign Language Learning and Children: The Parental Role (ED 289366).

Shipton I., Mackenzie AS., \& Shipton J. (2006). The Child as a Learner. British Council and BBC.Retrieved from http://www.teachingenglish.org.uk

Watzke, J. L. (2003). Lasting change in foreign language education: A historical case for change in national policy. Westport, CT: Praeger Publishers.

Young, A. S. (1994). Motivational State and Process within the Socio-Linguistic Context. Birmingham: Aston University.

Young, R.L., \& Tran, M.T. (1999). Vietnamese Parent Attitudes Toward Bilingual Education. Bilingual Research Journal, 23. Retrieved July 17, 2009 from http://brj.asu.edu

YPEPTH. (2010). English in the first School Years. Retrieved from http://www.YPEPTH.gr 